\title{
Recombinant Interleukin-1-beta
}

National Cancer Institute

\section{Source}

National Cancer Institute. Recombinant Interleukin-1-beta. NCI Thesaurus. Code C585.

A recombinant therapeutic agent which is chemically identical to or similar to the endogenous protein cytokine interleukin 1 (IL-1)-beta. Produced by monocytes and activated macrophages, endogenous mature IL-1 is generated through proteolytic cleavage by proteases such as IL-1-beta converting enzyme (ICE). This agent promotes angiogenesis, fibroblast proliferation, and neutrophil chemotaxis; it also regulates the functions of lymphocytes and epithelial cells and is involved in the 'acute phase response' to infection. ( $\mathrm{NCl04)}$ 